Summer 2013

\title{
The Recurring Native Response to Global Labor Migration
}

Patrick W. Thomas

Indiana University Maurer School of Law, thomas.patrick@gmail.com

Follow this and additional works at: https://www.repository.law.indiana.edu/ijgls

Part of the Immigration Law Commons, International Law Commons, and the Labor and Employment Law Commons

\section{Recommended Citation}

Thomas, Patrick W. (2013) "The Recurring Native Response to Global Labor Migration," Indiana Journal of Global Legal Studies: Vol. 20 : Iss. 2 , Article 28.

Available at: https://www.repository.law.indiana.edu/ijgls/vol20/iss2/28

This Note is brought to you for free and open access by the Law School Journals at Digital Repository @ Maurer Law. It has been accepted for inclusion in Indiana Journal of Global Legal Studies by an authorized editor of Digital Repository @ Maurer Law. For more information, please contactrvaughan@indiana.edu.

\section{$\Psi$}

JEROME HALL LAW LIBRARY

INDIANA UNIVERSITY

Maurer School of Law
Bloomington 


\title{
The Recurring Native Response to Global Labor Migration
}

\author{
PATRICK W. THOMAS*
}

\begin{abstract}
For the past few decades, and increasingly in the past few years, U.S. state governments have supplemented federal immigration law with state laws overtly designed to combat the perceived ills stemming from undocumented immigration to the United States. Proponents of these laws justify them on the basis of a normative negativity associated with "illegal" immigration, and negative economic consequences for natives. They further disclaim any discriminatory motive behind the laws, claiming that the laws only target "illegal" immigration.

This note argues that (1) through a comparison with immigration flows and laws arising in the First Era of Globalization in the late 1800 s, these new laws represent a predictable nativist response to global flows of labor migrants, and, though they are facially justified on grounds of "illegality," such a justification overshadows a deeper discriminatory justification, which anti-Chinese laws arising in the First Era of Globalization made no pretense of veiling. Further, this note argues that (2) these laws are normatively misguided, particularly in the face of relentless globalizing processes that strengthen migration incentives and the economic good which could be acquired through reduced barriers to global labor migration.
\end{abstract}

\section{INTRODUCTION}

Over the past two centuries, global migration patterns have ebbed and flowed in response to changes in immigration control regimes, domestic politics, and mobility in capital, trade, and labor. Immigration control regimes have moved along similar lines, often reflecting racial, cultural, and social animosity that an influx of dissimilar "others" can create. Yet, the United States federal government first implemented

* J.D. 2013, Indiana University Maurer School of Law.

Indiana Journal of Global Legal Studies Vol. 20, Issue 2 (2013)

(C) Indiana University Maurer School of Law 
immigration restrictions ${ }^{1}$ with the Page Act of $1875 .^{2}$ The federal government later broadened such restrictions in 1880 through the renegotiation of the Burlingame Treaty with China, which allowed the United States to restrict Chinese immigration writ-large. ${ }^{3}$ A populist backlash against these new and dissimilar immigrants ${ }^{4}$ led to the Chinese Exclusion Act of 1882, which banned Chinese immigration-squarely on the basis of race and nationality-for ten years. 5 Thus, for over one hundred years, immigration to the United States was based on the global labor market, subject only to the most lenient regulations.

The period from approximately 1880 until 1914, in which Congress passed the Chinese Exclusion Act, is known as "The First Era of Globalization."6 Before this period, approximately one hundred years after the adoption of the Constitution, there were no federal immigration regulations in the United States. There were, however, various state ${ }^{7}$ and local immigration regulations that appeared during this time-though the federal government often successfully challenged

1. The federal government did have some statutory authority to expel immigrants prior to this time under the Alien and Sedition Acts. See An Act Concerning Aliens, 1 Stat. 570, 570-571 (1798) (giving the President the power to order departure of all aliens who, in the President's discretion, were judged "dangerous to the peace and safety of the United States" or whom the President suspected were conspiring against the government). However, no broad classification of immigrants was excluded or deportable from the United States before the Page Act of 1875.

2. Elthne Lulbheld, Entry Denied: Controlling Sexuality at the Border 31 (2002). The Page Act prohibited the immigration of convicts, prostitutes, and forced laborers from Asia. The Page Act of 1875, 18 Stat. 477, 477-78. The prostitution provision was heavily enforced, especially against Chinese women immigrants, while the others were not. LULBHELD, supra, at 31. For further background on the Page Act and its effects, see Kerry Abrams, Polygamy, Prostitution, and the Federalization of Immigration Law, 105 COLUM. L. REV. 641, 643-47 (2005).

3. Hiroshi Motomura, Americans in Waiting: The Lost Story of Immigration AND CITIZENSHIP IN THE UNITED STATES 17 (2006).

4. I use the same definition of "immigrant" here as does the U.S. Code: An immigrant is a noncitizen of the United States, who intends to move to the United States to live and work permanently. See 8 U.S.C. $\$ 1101(a)(3)$ (2012). This definition is distinct from those noncitizens in the United States who have legal authorization to remain in the country, but for a definite period of time, subject to certain conditions. See 8 U.S.C. $\S$ 1101(a)(15)(A)-(V).

5. MotomuRA, supra note 3, at 25.

6. Moritz Schularick \& Thomas M. Steger, Financial Integration, Investment, and Economic Growth: Evidence from Two Eras of Financial Globalization, 92 REV. ECON. \& STAT. 756, 757 (2010).

7. Unless otherwise indicated, "state" refers to one of the individual states of the United States. 
these laws on various constitutional grounds. ${ }^{8}$ These state immigration laws often reflected vicious racial, social, and cultural biases, which emerged as a result of the increased migration that the empty American interior necessitated, and that the First Era of Globalization encouraged.

Today, the federal government has caught up to the states in its regulation of immigration. A myriad of immigration laws fills Section Eight of the United States Code, along with numerous executive regulations. These laws have grown largely out of labor necessities, family reunification desires, and humanitarian aspirations. Nevertheless, an influx of racially, socially, and culturally disparate peoples into any given political space still produces immigration laws which reflect racial, social, and cultural animosities, whether stated squarely on the face of the laws, or hidden within subtler justifications. Federal immigration law has historically been no stranger to this trend.

Furthermore, states still perceive-sometimes in contravention of reality-that the federal government is not regulating properly or enough. In our current era of globalization, the subtle racially, socially, and culturally biased laws have reemerged in the context of state regulation of immigration. States have not justified recent restrictionist laws reflecting these biases directly on these bases-such an overt admission would be untenable politics and likely unconstitutional today. ${ }^{9}$ Rather, the states justify the laws on the basis of immigrants' "illegality," and the economic harm that immigrants supposedly do to natives. ${ }^{10}$

Yet, these arguments prove specious. As this note will elaborate upon later, unrestricted legal immigration into the United States would no doubt still provoke equal dismay from immigration opponents. While breaking the law can certainly be normatively "bad," a further

8. See, e.g., Smith v. Turner (Passenger Cases), 48 U.S. 283 (1849) (striking down New York and Massachusetts statutes that imposed a tax on foreigners leaving state ports as violating the federal government's exclusive authority to control commerce between the United States and foreign nations).

9. But see Dunn v. INS, 499 F.2d 856, 859 (9th Cir. 1974) (applying rational basis review to a statute denying adjustment of status only to western hemisphere countries including Mexico).

10. See, e.g., S.B. 1070, 2d Reg. Sess. $\$ 1$ (Ariz. 2010) (codified at ARIZ. REV. STAT. ANN. $\S 11-1051(\mathrm{~A})(2012)$ (declaring an intent to "discourage and deter the unlawful entry and presence of aliens and economic activity by persons unlawfully present in the United States.”); Beason-Hammon Alabama Taxpayer and Citizen Protection Act, 2011 Ala. Laws $535, \S 2$ (finding that "illegal immigration is causing economic hardship and lawlessness in the state"). To the extent that national restrictionist advocacy organizations have influenced state legislators to pass such laws, see, e.g., Illegal Aliens Taking U.S. Jobs, FED'N AM. IMMIGR. REFORM, http://www.fairus.org/issue/illegal-aliens-taking-u-s-jobs (last visited June 25, 2013). 
justification is necessary to condemn "illegal" immigration; ${ }^{11}$ if the same group of people migrated under laws that removed their illegality, immigration opponents would still undoubtedly have misgivings. Further, the literature on labor migration economics universally suggests that pro-immigration policies invariably lead to economic growth-both in sending and receiving countries and among natives and new immigrants. Moreover, the pressures of unemployment and depressed wages that immigration opponents often fear, have, at the very least, been overstated.

So, what is really behind these laws? This note first argues that the unique form of globalization that has been occurring for the past few decades has served (1) to set the underlying conditions for increased global labor migration, and (2) to inculcate nativist attitudes in the United States to such a degree that economically driven and evidence-based legislation has become difficult, if not impossible, in this arena. This argument applies with particular force to the state legislatures, which are more responsive to popular attitudes.

In this note, I strive to use these two eras of globalization-the First Era and the Current Era-as lenses through which to view the mechanisms, justifications, and ultimate effects of immigration regulations that have arisen due to globalizing processes. Ultimately, globalization does serve to increase native hostilities to foreign labor migrants, due to perceived negative effects on native employment and wage rates. In reality, however, the fullest exercise of globalization-removing any barriers to labor migration-would have at least a neutral effect on native employment and wage rates, and a positive effect on migrant employment and wage rates. Nevertheless, as a result of the perceived effects, state legislators have drawn up laws that subtly discriminate on racial, social, and cultural norms-just as in the First Era of Globalization. These laws reveal that, faced with

11. A further word on semantics: The term "illegal immigration" has been used for decades by immigration opponents, politicians, and the media to describe mainly those who come to the United States without any valid immigration status or visa. The term is at once over- and under-inclusive. If the term means "violators of immigration law," the popular conception does not necessarily encompass a Polish student who overstays her $\mathrm{F}$ Visa or even a lawful permanent resident of forty years, who is rendered deportable for possession of marijuana. Yet, it may also include illegal entrants, who have subsequently acquired temporary protection or an interim status, and are now present lawfully. The term also unfairly conflates criminality to such law violations, where the vast majority of enforcement occurs in a civil context. However, the popular conception still prevails, and since this work serves in part to respond to restrictionist arguments, I will use the term. Where I use it, it refers only to those who entered the United States without status, and remain without status, or immigrants with expired status (i.e., the Polish student mentioned above in this footnote). 
evidence for the positive effect of labor migrants on domestic economies, state legislators may, alternatively, be experiencing information asymmetry or cognitive dissonance, or basing their restrictionist laws on racial, national, or cultural biases. But today, rather than justifying these discriminatory laws on restricting an undesirable race, religion, political affiliation, nationality, or culture, ${ }^{12}$ legislators justify the laws on the basis of a migrant's "illegality."13 Illegality, however, often gets caught up in intractable ways with discriminatory racial, societal, and cultural associations; moreover, these negative associations blend over into fully "legal" immigrants. Thus, globalization pushes the same results as in the past, but with a minor justificatory alteration in light of modern political and legal realities.

First, this note will discuss globalization in general, seeking to lay down a few key definitions-noting in particular the globalizing processes of the First and Current Eras of Globalization. Thereafter, this note will outline targeted immigration laws: first, focusing on those arising just before and through the First Era of Globalization; then, outlining the various state immigration regulations akin to Arizona's S.B. $1070 .{ }^{14}$ Specifically, I will note the mechanisms, intended and actual effects, ${ }^{15}$ and justifications of these laws. To critique these justifications, the economics literature on globalized migration will be examined, along with the notion of "illegality" as a justification for the

12. See, e.g., FAQ, FED'N AM. IMMIGR. REFORM, http://www.fairus.org/faq (last visited Mar. 2, 2013) (disclaiming favoring immigration policies that discriminate "on the basis of race, creed, color, religion, gender or nationality").

13. See Illegal Immigration, FAQ, FED'N AM. IMMIGR. REFORM, http://www.fairus.org/ issues/illegal-immigration (last visited Mar. 2, 2013). Note especially that, among various issues in immigration policy, "illegal immigration" is the most highlighted issue on FAIR's website.

14. There are many other important examples of state immigration regulations, many of which are pro-immigrant. See Illinois DREAM Act, 2011 Ill. Legis. Serv. 97-233 (West) (making scholarships, college savings, and prepaid tuition programs available for undocumented immigrant students who graduate from Illinois high schools); A.B. 131, 2011 Leg., Reg. Sess. (Cal. 2011) (making in-state tuition available for undocumented immigrants). Some reflect the biases mentioned in this paper, while others do not. However, for ease of comparison and the public importance and notoriety of these laws, this paper's focus is on SB 1070 and its copies in other states.

15. Many of these laws remain under preliminary and permanent injunctions as a result of constitutional challenges by immigrants and the U.S. federal government. See Arizona v. United States, 132 S.Ct. 2492 (2012); Ga. Latino Alliance for Human Rights v. Georgia, 691 F.3d 1250 (11th Cir. 2012); Hispanic Interest Coal. of Ala. v. Governor of Alabama, 691 F.3d 1236 (11th Cir. 2012); United States v. Alabama, 691 F.3d 1269 (11th Cir. 2012); Friendly House v. Whiting, 846 F. Supp. 2d 1053 (D. Ariz. 2012); Buquer v. Indianapolis, 797 F. Supp. 2d 905 (S.D. Ind. 2011); United States v. South Carolina, 840 F. Supp. 2d 898 (D.S.C. 2011). Thus, we may not know their actual effects for some time, if ever. 
new laws, as well as a process of sociopolitical "illegalization." The note will conclude with some normative thoughts on how to reframe our political discussion of these issues to approach the reformation of what many consider a "broken" immigration system from a more constructive perspective.

\section{GLOBALIZATION AND GLOBAL LABOR MigRATION}

Broadly defined, globalization is the increased integration of the globe along a number of different axes. ${ }^{16}$ Materially, globalization includes the economy, culture, and society at large. ${ }^{17}$ Much literature on globalization discusses its economic aspects: indeed, though a wide array of disagreement exists on globalization's effect on, and integration with, the global economy-and even on its very existence as an epistemological method for studying the global economy-all sides agree that the world has seen greater global economic integration during this current period of globalization. ${ }^{18}$

Yet, according to globalization scholars-and implicit in a common understanding of the term-globalization has also had profound effects on societal, cultural, political, and technological developments worldwide. ${ }^{19}$ These effects, arguably, derive largely from the integration of the global economy, because otherwise there would be less incentive for these types of changes. Nevertheless, these noneconomic sectors are critically important to globalization-both as an academic field of study and to the common conception of the term.

\section{A. Global Labor Migration}

Global labor migration fits into the overarching globalization mold, mixing with economic conceptions of globalization in critical ways, but ultimately more publically perceived as social and cultural aspects of the concept. Globalization is (1) a driver of immigration, through a couple of mechanisms that will be discussed later, (2) an external concept for natives impacted by global labor migration, and finally, (3) a tool for comparing laws and other responses during different periods of high global labor migration.

16. David Held \& Anthony McGrew, The Great Globalization Debate: An Introduction, in The Global Transformations REader 1, 3 (David Held \& Anthony McGrew eds., 2d ed. 2003).

17. Id.

18. Id. at 6.

19. Id. 
First, globalization drives global labor migration through the integration of the global economy, which is marked by an exponentially increased focus of producers on a non-national market orientation. ${ }^{20}$ In turn, these producers lobby for (and often receive) liberalization of capital and trade restrictions, ${ }^{21}$ which are justified on David Ricardo's theory of comparative advantage. ${ }^{22}$ In this manner, multinational enterprises are able to proliferate and spread their reach much more easily across the world. This easing of trade and capital, in turn, incentivizes firms and some policymakers to seek easing of the movement of people (employees, executives, and trading partners), as well. ${ }^{23}$ I refer to this phenomenon as the "Global Mobility Triad."

Not only do transnational entities wish to ease the movement of people, but globalization has also made emigration more attractive-due heavily to the wealth and income disparities that globalization has exacerbated. ${ }^{24}$ These disparities have produced a strong incentive for unskilled labor migrants to emigrate to richer countries with higher wage rates, as can be seen with Mexico-U.S., Morocco-Spain, and Indian-U.A.E. labor flows, among others. Even in the face of physically arduous journeys and harsh anti-immigration laws, the utility calculus still continues to weigh in favor of migration. ${ }^{25}$

Secondly, global labor migration is part of the globalization that people perceive as an external force. That is, from a citizen's perspective, globalization is a force that acts from outside of the respective polity. ${ }^{26}$ This viewpoint is fundamentally flawed, as globalization is not an external force, but rather is deeply embedded in

20. Peter Dicken, $A$ New Geo-economy, in The Global Transformations Reader, supra note 16 , at 303 .

21. See, e.g., North American Free Trade Agreement pt. I-III, Dec. 17, 1992, 32 I.L.M. 296-456; North American Free Trade Agreement pt. IV-VIII, Dec. 17, 1992, 612-799, 649-57, 663-64, 671-80.

22. David Ricardo, The Principles of Political Economy and Taxation 80 (3d ed. 1821), available at http://www.econlib.org/library/Ricardo/ricP.html. This theory holds that, since all countries have an unequal endowment of production factors (labor, land, and capital), countries will import whatever is most expensive for them to produce, and export what is best produced given the particular set of economic factors.

23. See, e.g., THE WORLD BANK, GLOBAL ECONOMIC PROSPECTS: ECONOMIC IMPLICATIONS OF REMITTANCES AND MIGRATION 25-26 (2006).

24. Though globalization scholars from many different stripes disagree on the importance, magnitude, and solutions for the income/wealth gaps seen today, all agree that in some way or another, globalization has encouraged these results. See Held \& McGrew, supra note 16, at 28-31.

25. To some degree, the 2008 recession has dampened these flows in the United States. See generally JEFFrey S. PASSEL \& D'VERA COHN, PEW RESEARCH CENTER, UNAUTHORIZED IMMIGRANT POPULATION: NATIONAL AND STATE TRENDS, 2010 (2011).

26. John Clarke, Turning Inside Out? Globalization, Neo-liberalism and Welfare States, 45 ANTHROPOLOGICA 201, 202, 205-06, 209 (2003). 
local and national processes throughout the world. ${ }^{27}$ Yet, global labor migration's "externality" - among natives considered largely a negative conception-is important to keep in mind, especially regarding potential policy prescriptions. To many, globalization and increased immigration are part of the same external "problem," and immigration restrictions are oftentimes justified on the basis of combating globalization's perceived deleterious effect on native workers. ${ }^{28}$

Natives often see globalization and increased immigration as cheapening the quality of traditional citizenship among natives, insofar as citizenship is defined as granting a set of entitlements. Specifically, restrictionist advocates cite the increased fiscal cost, which immigrants-legal or otherwise-bring to their receiving countries, as a justification to slow immigration flows. 29 Following this theory, resources become scarcer for citizens who are more deserving of these entitlements-by virtue of their bloodline-after immigration flows increase. ${ }^{30}$ Additionally, heterogeneous immigrants necessarily take away the relative homogeneity of a receiving country's population, which many also perceive as taking from the concept of citizenship. ${ }^{31}$

However, globalization has more broadly changed the concept of citizenship and belonging in more fundamental ways, both for the citizen and noncitizen. Kitty Calavita suggests that globalization has weakened the position of citizens relative to their corresponding territorial nation-states. The rights and freedoms that used to inure in the citizenship concept have diminished to a degree. Our "social space" has changed so that the shopping mall has replaced our public forums, and membership in a community now presupposes membership in the consumer market. ${ }^{32}$ Calavita suggests that because of an immigrant's

27. Id. at 205-06.

28. See, e.g., PBS Newshour: Free Trade Hurts American Workers, AFL-CIO Director Says (Feb. 14, 2007), http://www.pbs.org/newshour/bb/business/jan-june07/globalization_0 2-14.html.

29. See, e.g., Jack Martin \& Eric A. Ruark, Fed'n Am. Immigration Reform, The Fiscal BURDEN OF ILLEGAL IMMigration ON UNITED STATES TAXPAYERS 87 (2011).

30. But not by their place of birth. Restrictionist advocates detest the jus soli aspect of citizenship as it exists in the United States, since undocumented immigrants can imbue U.S. citizenship in their children simply by giving birth to them within the United States. See id. at 5.

31. Notably, this effect is much more apparent in Europe and other countries than in the United States. This is especially so, since the United States' foundation myth is itself based on immigrants of different ethnicities and languages, in contrast to the ethnicity-based foundation myths of European countries and others. Jack Citrin \& John Sides, Immigration and the Imagined Community in Europe and the United States, 56 POL. STUD. 33, 34 (2008).

32. KitTy Calavita, Immigrants at the Margins: Law, Race, and EXClusion in SOUTHERN EUROPE 163 (2005). 
perceived inability to participate in consumption, they cannot belong to the social space of the post-modern, globalized world. ${ }^{33}$

Calavita's theory may reinforce the theories behind an immigrant's exclusion by the global elite. Extending the theory, immigrants are perceived as taking native jobs away-and thus taking natives out of the new social space of consumption. Thus, labor-driven immigrants are seen not only to usurp a native's traditional citizenship, but also their position as a consumer, which is now central to the conception of belonging in a globalized world. Accordingly, immigration regulations justified on immigration's perceived negative economic impact may find greater support among natives under this logic.

\section{B. The Response of the United States to Global Labor Migration}

Taken together, the forces and concepts of globalization have uniquely altered global migration flows, shaped the corresponding responses of nation-states, and exacerbated the above-mentioned racial, cultural, and societal animosities in profound ways. Nation-states have responded to these changes with a variety of measures, not all of them successful. Protectionist fears-both economic and sociocultural-drive some responses, while pragmatic and economics-based incentives drive others.

The United States has chosen to develop a complicated immigration strategy, where legal immigration is contingent on (1) family or employer ties to the United States, ${ }^{34}$ (2) ability to pay, and (3) lack of disqualifying factors such as criminal or terrorist behavior, public health risks, and a wide variety of others. ${ }^{35}$ Because of this high bar, many intending immigrants to the United States-especially from Mexico and other proximate Central American countries-have chosen to skirt the legalities of the U.S. immigration regime and enter illegally, for the very reasons globalization has pushed those immigrants. The United States civilly punishes illegal entrants with removal upon notification of their "entry without inspection," with some relief provisions available in select cases. ${ }^{36}$

33. Id.

34. For statutes relating to immigration paths for relatives of U.S. citizens and legal permanent resides see 8 U.S.C. $\$ \S 1151$ (2012) and id. $\S 1153$.

35. See 8 U.S.C. $\S 1182$ (2012) (relating to inadmissibility factors); id. $\S 1227$ (relating to deportability factors).

36. See 8 U.S.C. $\S \S 1182(a)(6)(A),(a)(9)$ (2012), 1227(a)(1)(A) (entry without inspection); id. $\S 1229 \mathrm{a}$ (removal proceedings); $i d$. $\S 1229 \mathrm{~b}$ (cancellation of removal and adjustment of Status); id. $\S 1229 \mathrm{c}$ (voluntary departure). 
Such deterring factors have not quelled the quest for the perceived riches of the United States. Illegal immigration flows continued to surge in the $2000 \mathrm{~s}$, and after a dip from the global recession in 2008, the flows remain strong still today. ${ }^{37}$ According to 2011 data from the Pew Research Center, approximately 11.1 million unauthorized workers live in the United States today. ${ }^{38}$ Even after numerous countermeasures were taken at the federal level, 39 illegal immigration to the United States still occurs, albeit in reduced numbers.

As a result, certain individual states have resorted to restrictionist immigration laws. These laws vary to some degree, but all attempt to (1) expand the authority and responsibilities of state and local law enforcement officials in enforcing federal immigration law, and (2) make life difficult for unauthorized immigrants in their respective jurisdictions. Many of these laws have been preliminarily declared unconstitutional, but some have withstood constitutional scrutiny, and litigation is still pending. ${ }^{40}$ Their constitutionality notwithstanding, these restrictionist laws suggest not only discontent with the federal government's enforcement of immigration or "illegal" immigration, but with immigration itself. Further, the effect of these so-called "Juan Crow" laws ${ }^{41}$ has indeed served to turn some of these states into no-man zones for immigrants, legal ${ }^{42}$ or not-especially Alabama, where the most stringent of provisions had previously survived judicial review. ${ }^{43}$

Restrictionist advocacy groups have justified these laws by noting that (1) "illegal" immigration skirts the rule of law-i.e., illegal immigration is bad, because of its illegality; ${ }^{44}$ (2) illegal immigration is a national security concern, because those who cross the border illegally

37. See PASSEL \& COHN, supra note 25 , at 1.

38. See Jeffrey Passel \& D'Vera Cohn, Unauthorized Immigrants: 11.1 Million in 2011, PEw HISPANIC CENTER (Dec. 6, 2012) http://www.pewhispanic.org/2012/12/06/unauthor ized-immigrants-11-1-million-in-2011/.

39. See, e.g., Secure Fence Act of 2006, Pub. L. No. 109-367, 120 Stat. 2638.

40. See, e.g., United States v. Alabama, 691 F.3d 1269 (11th Cir. 2012); Hispanic Interest Coal. of Ala. v. Alabama, 691 F.3d 1236 (11th Cir. 2012).

41. David Person, 'Juan Crow' Law Alive in Alabama, USA TODAY (Nov. 1, 2011, 5:28 PM), http://usatoday30.usatoday.com/news/opinion/forum/story/2011-11-01/alabama-illega l-immigration-law/51031138/1.

42. Phillip Rawls, Many Legal Immigrants Leaving Alabama Behind, SPOKESMAN-REV. (Oct. 11, 2011), http:/www.spokesman.com/stories/2011/oct/06/many-legal-immigrants-lea ving-alabama-behind/.

43. See, e.g., United States v. Alabama, 813 F. Supp. 2d 1282, 1345 (S.D. Ala. 2011) (upholding a prohibition on contracts with unlawfully present aliens), rev'd, 691 F.3d 1269 (11th Cir. 2012).

44. See, e.g., Lamar Smith, Adhere to the Rule of Law on Immigration Policy, WASH. TIMES (Mar. 24, 2010), http://www.washingtontimes.com/news/2010/mar/24/smith-adhereto-rule-of-law-on-immigration-policy/. 
are not inspected for health, security, or criminal concerns, like legal immigrants-though not necessarily natural-born citizens-would be;45 (3) illegal immigration applies negative fiscal pressures on states and the federal government; 46 and (4) immigration of any type takes jobs and wages away from more deserving natives. ${ }^{47}$

This note argues that these laws are misguided and their underlying justifications are specious. In essence, these laws are strikingly similar to the anti-Chinese laws of the First Era of Globalization-with nearly identical justifications. An economic analysis of labor migration does not lead to the conclusion that migrants unduly hurt native wage rates; rather, the analysis shows that these rates remain relatively unchanged or show only very weak losses. Further, the global economy gains from migrant movement and gross world product increases, as labor migrants would not move without a likelihood of increasing their economic well-being. 48 In addition, the gross domestic product of both sending and receiving countries increases.

Additionally, the argument surrounding illegality can be easily disarmed. Were there no restrictions on immigration, "illegal" immigration would not be a problem per se, as no immigrant could violate nonexistent immigration law. Yet, the restrictionist lobby would undoubtedly call for some restriction, even though there were no "illegal" 49 immigrants to catch. This is because such organizations are opposed not only to "illegal" immigration, but immigration itself. 50

Further, even if there were some restrictions on immigration, such as designated entry and exit waypoints or a ban on felons, a system that allowed for the migration of poor, unskilled laborers ${ }^{51}$ would mitigate rational national security concerns. Immigration enforcement

45. See, e.g., Rowan Scarborough, Illegal Immigration is a National Security Issue, HuM. EvENTS (May 6, 2010, 3:01 AM), http://www.humanevents.com/article.php?id=3685 1 .

46. See generally MARTIN \& RUARK, supra note 29 (discussing the concerns of cost related to health, security, and criminal activity).

47. See generally ERIC A. RuARK \& MatThew Graham, FED'N AM. IMMIGR. REForm, IMMIGRATION, POVERTY, AND LOW WAGE EARNERS: THE HARMFUL EFFECT OF UNSKILLED IMMIGRANTS ON AMERICAN WORKERS (2011).

48. See infra Part III.

49. Insofar as the term applies to the group of people who fit the common conception of "illegal immigrants." See supra note 11. I do not refer to those who are "illegal" because of substantive criminal or security concerns that make them inadmissible to or deportable from the United States.

50. See FED'N AM. IMMIGR. REFORM, AN IMMIGRATION REFORM AGENDA FOR THE 112TH CONGRESS 7-8 (2011) (calling for a reduction in overall immigration levels to the United States).

51. See infra Part III, B. 
authorities would be free to focus on true illegality-i.e., those who skirt the entry or exit requirements because of criminal, security, or other serious issues that are otherwise unrelated to qualifying for immigration status.

Instead, our focus on "illegal" immigration obscures the target of our national immigration policy; to be "illegal," something must be "illegalized." The nineteenth and early twentieth centuries' immigration laws illegalized Chinese immigrants because of their race and nationality. ${ }^{52}$ Yet, the rhetoric spoke of exclusion based on race, nationality, or other characteristics-not illegality. Today, we have illegalized another group-not facially on the basis of race, but on socioeconomic lines: low or unskilled, poor workers from developing nations. State laws that build on this new policy work within the framework of immigrant "illegality." This definition often gets caught up in discriminatory racial, societal, and cultural notions, and will be explored later. Policymakers cannot forget that by rallying against "illegal" immigration, one should never forget who has been "illegalized," whether directly by race, nationality, or otherwise.

Finally, from a normatively global standpoint, diminished borders and increased migration bring the world a net good. They do so for a variety of reasons, some of which are peculiar to the United States. First, freer movement of labor-helped along by economic globalization-is normatively good for the world and local economies. Given the currently depressed state of such economies, freer immigration policies would be a welcome boon. Second, a freer immigration policy meshes well with the historical notion of citizenship and belonging in the United States. Because the identity of a United States citizen is not intrinsically tied to an ethnicity-which is different from countries as disparate as France, Germany, Saudi Arabia, or Japan-it is much easier, politically and practically, to adopt such a system. ${ }^{53}$ Finally, a "freer" immigration control policy does not require (nor should it) a system of absolute free immigration. Both to make such a policy palatable to resistant constituencies and to provide for effective international efforts against crime and terrorism, the securitization of borders should be preserved.

52. Among other racial, social, and even political groups. See, e.g., Immigration Act of 1917, 39 Stat. 874, 875-77 (1917) (barring all homosexuals, criminals, "idiots, . . . feeble-minded persons, epileptics, insane persons, . . alcoholi[cs], . . professional beggars, . . . polygamists, ... anarchists," illiterates, and anyone from a wide swath of Asia, extending from the Ottoman Empire to present-day Papua New Guinea, from admission to the United States).

53. See Citrin \& Sides, supra note 31 , at 34 . 


\section{IMMIGRATION REGULATION IN A GLOBALIZING CONTEXT}

This section will explore the foundations and dynamics of the relative periods of globalization and analyze their corresponding anti-immigration laws. Four areas of inquiry exist in this section: First, what are the laws and what is their structure? Second, what are the goals behind the laws? Third, what are the laws' actual effects, and do they comport with the laws' goals? Finally, what were the justifications underlying these laws, do the goals and effects necessarily follow from them, and are they normatively sound?

\section{A. The First Era of Globalization}

The influx of foreign laborers to the United States in the mid- to late-1800s was part and parcel of globalizing processes and a globalizing mindset at work during this era. Largely thanks to heavy European investment, international trade and capital transfers rose significantly. ${ }^{4}$ Further, there were few barriers to the flow of goods-and virtually none for capital. And, during this period-as opposed to the current period of globalization-people could flow a great deal easier, at least from a legal perspective. Here, all three points of the Global Mobility Triad are visible. This was thanks to, among other factors, lax border controls, the influence of powerful business interests, and overall elite support for open migration. ${ }^{55}$ Today, technology has facilitated both better availability of quick travel and a greater integration of peoples around the world. The latter phenomenon might lay expectations that people should move, and travel, to their maximum benefit. However, today the will of the governing elite seems to be more responsive to popular nativist demands and less permissive of open immigration policies that business elite favored in the First Era of Globalization.

In the United States, this trend emerged in the middle of the nineteenth century. The opening of the American frontier brought owners of capital and land, but few laborers to work the land or fill its factories. Owing to this, and the Irish Potato Famine from 1845 to 1852, Irish immigrants flowed into the United States in vast numbers. ${ }^{56}$

54. See Schularick \& Steger, supra note 6 , at 757.

55. But see Gerald L. Neuman, The Lost Century of American Immigration Law (1776-1875), 93 COLUM. L. REV. 1833, 1884 (1993) (contending generally that many state immigration laws existed-if not by name-prior to the Chinese immigration period, but conceding that these laws often did not actually prevent immigration).

56. Lawrence H. Fuchs \& Susan F. Martin, Select Commission on Immigration and Refugee Policy, U.S. Immigration Policy and the National Interest, in THOMAS A. 
Though they certainly encountered resistance from the natives, many Irish were eventually able to assimilate into American society, given their relative racial homogeneity. ${ }^{57}$

The next wave of immigrants was not so fortunate. A large influx of Chinese immigrants resulted from increasing work opportunities in the American West provided by the California Gold Rush, and later on the Transcontinental Railroad. ${ }^{58}$ From 1860 to 1890 , Chinese immigrants constituted about 9 percent of California's population..$^{59}$

Anti-Chinese sentiment among natives was rampant. Initially, native miners organized against attempts to import cheaper Chinese labor, especially in mining camps where native miners tended to congregate. ${ }^{60}$ The resistance movement eventually moved to the cities, where Chinese immigrants had concentrated in "Chinatowns."

After meeting with limited success at the grassroots level, anti-Chinese activists petitioned their local and state governments for redress. The California state government first responded in 1850 with a tax on foreign miners, and eventually attempted to bar Chinese immigrants from working, and even living, in California cities. ${ }^{61}$ Many towns passed ordinances barring Chinese immigrants from working in occupations that were typical for the Chinese population, such as mining, fishing, and Laundromat operations. ${ }^{62}$ Anti-Chinese activists also attempted to deny civil rights to the Chinese population, even to permanent residents and U.S. citizens of Chinese ancestry. Some towns even attempted to directly forbid Chinese immigrants from living within their municipalities. ${ }^{63}$ Even the Supreme Court of California held that a white man, accused of murder based solely on the testimony of Chinese witnesses, could not be found guilty of murder under California law, because the witness' race rendered them incompetent to testify. ${ }^{64}$

Ultimately, however, these efforts faced strong resistance from the business community and religious leaders, and many were ruled as either unconstitutional or violating the Burlingame Treaty. ${ }^{65}$ These

Aleinkoff et AL, Immigration and Citizenship: Process and Policy 158, 161-64 (6th ed. 2008).

57. Id. at 163 .

58. Eric W. Fong \& William T. Markham, Anti-Chinese Politics in California in the 1870s: An Intercounty Analysis, 45 SOC. PERSP. 183, $187-88$ (2002).

59. Id. at 187.

60. Id. at 189 .

61. Id. at 189, 193.

62. See, e.g., Yick Wo v. Hopkins, 118 U.S. 356 (1886) (laundry).

63. Fong \& Markham, supra note 58, at 193.

64. See People v. Hall, 4 Cal. 399 (1854).

65. Fong \& Markham, supra note 58, at 191. See also, e.g., Lin Sing v. Washburn, 20 Cal. 534 (1862) (holding a head tax on Chinese immigrants in certain industries as 
defeats eventually led to national action with the Chinese Exclusion Act.66 In a surprise to many modern Americans, prophylactic immigration restrictions at the federal level did not exist until this time. ${ }^{67}$ The Chinese Exclusion Act barred Chinese immigration to the United States for a period of ten years, was renewed multiple times, and ultimately made permanent in $1904 .{ }^{68}$ The Act was not repealed until 1943.69

The Chinese Exclusion Case, which upheld the constitutionality of the Act, cites the justifications for many of these laws. The Supreme Court quotes from the proceedings of California's constitutional convention, when it constructed California's second constitution:

[T]he presence of Chinese laborers had a baneful effect upon the material interests of the state, and upon public morals; that their immigration was in numbers approaching the character of an Oriental invasion, and was a menace to our civilization; that the discontent from this cause was not confined to any political party, or to any class or nationality, but was ... universal; that they retained the habits and customs of their own country, and ... constituted a Chinese settlement within the state, without any interest in [the United States] or its institutions."70

Thus, culminating with the Chinese Exclusion Act, the First Era of Globalization saw a long arc of nativist legislative response to open immigration policies in the United States. Unfortunately for business owners and migrants, nativist policy goals controlled Congress during this period. Additionally, the Supreme Court refused to strike down

preempted by federal immigration law); Ho Ah Kow v. Nunan, 12 F. Cas. 252 (C.C.D. Cal. 1879) (holding that San Francisco violated the Fourteenth Amendment's Equal Protection Clause when it enforced an ordinance requiring "queues" - a then-vogue braided hairstyle among Chinese men-to be cut off during a course of imprisonment).

66. Chinese Exclusion Act, ch. 126, 22 Stat. 58 (1882) (repealed 1943).

67. Laws referring to and regulating citizenship and naturalization did arise prior to this. See, e.g., U.S. ConsT., art. I, $\S 8$, cl. 4, amend. XIV. In addition, the Alien and Sedition Acts did grant the President power to deport certain "dangerous" aliens after arrival in the United States, but no federal law-with the exception of the Page Act, see LULBHELD, supra note 2-had created a class of aliens to whom entry was flatly denied.

68. Act of Apr. 27, 1904, ch. 1630, 33 Stat. 428.

69. Magnuson Act, ch. 344,57 Stat. 600 (1948) (codified at 8 U.S.C. $\$ \S 49,262,263-71$, 293, 294, 299).

70. Chae Chan Ping v. United States (Chinese Exclusion Case), 130 U.S. 581, 595-96 (1889) (emphasis added). 
these restrictions on constitutional grounds-establishing the broad authority given to Congress and the executive branch under the plenary power to regulate immigration and naturalization laws. ${ }^{71}$

Lastly, it is important to outline the structure, effects (both intended and actual), and justifications for these laws, for effective comparison to current state immigration laws. For laws from this era, the process is rather simple: structurally, these laws directly regulated the living conditions, work opportunities, and immigration legality of Chinese immigrants squarely on their race and nationality. These laws were directly intended to keep Chinese immigrants out of the political community, labor market, and, ultimately, off of the land itself. Though these laws ran into some backlash from business and religious communities-as well as from the Chinese immigrants themselves ${ }^{22}$-after the Chinese Exclusion Act, immigration opponents largely achieved their goals. Chinese immigration was flatly banned in the United States. Finally, the justifications of these laws should be readily apparent. The laws were prompted by a populist reaction to a culturally, societally, and racially distinct "other"; the society was afraid of economic despondency on the one hand, and cultural, societal, racial, and political fragmentation on the other. In short, the Chinese were "illegalized" on the basis of their race, because of economic and cultural fear.

\section{B. The Current Era of Globalization}

Today, the world has been undergoing a period of globalization since the fall of the Bretton Woods system in the $1970 \mathrm{~s} .{ }^{73}$ Contrary to the First Era of Globalization, the exponential growth of technology-especially in telecommunications and international travel-has led to much deeper economic integration than was possible in that era. Trade and capital move very quickly at the behest of transnational organizations; though, of course nation-states had to originally cede some of their sovereignty in trade and capital agreements. ${ }^{74}$

71. See generally id. at 603-10 (emphasizing the power inherent in the sovereign to exclude foreigners). Note that the plenary power receives particular deference because of its extra-constitutionality. See United States v. Curtiss-Wright Export Corp., 299 U.S. 304 (1936) ("investment of the federal government with the powers of external sovereignty did not depend upon the affirmative grants of the Constitution.").

72. Fong \& Markham, supra note 58, at 190.

73. Saskia Sassen, Territory, Authority, Rights: From Medieval To Global ASSEMBLAGES 167-68 (2008).

74. See, e.g., North American Free Trade Agreement (NAFTA), OFF. U.S. TRADE REPRESENTATIVE, http://www.ustr.gov/trade-agreements/free-trade-agreements/north-ame 
Here, two points of the Global Mobility Triad-capital and goods-appear again. However, today we live with a vast web of restrictive-and largely effective-migration regulations among the developed world. ${ }^{75}$ These restrictions were certainly not present in the First Era; and even though, and perhaps because, the proliferation of communications and transport technologies makes global migration possible, nation-states have built up legal barriers to immigrants worldwide - especially those from developing nations.

Why have nation-states built these walls and made the movement of people flow so slowly? This is an especially salient question given the great marginal economic gains that could be made by people across the world given more open migration policies. ${ }^{76}$

The two periods of globalization afford us an opportunity to compare their restrictionist laws and underlying justifications. Though it has been well over one hundred years since the passage of the Chinese Exclusion Act, the motives of humans do not change all that much when a racially, culturally, and socially disparate "other" moves into a territory that natives thought of as their "own." Yet, our political sensibilities-as well as newer constitutional directives-have made laws such as the Chinese Exclusion Act nearly untenable in the United States today. ${ }^{77}$

In comparing these laws to current globalization-driven restrictionist immigration laws, we find that, to achieve the same effect of keeping out undesirable "others," there are the same underlying patterns as in the First Era of Globalization, but couched in politically palatable rhetoric. The United States has once again "illegalized" a certain type of immigrant-not squarely on the basis of their race $^{78}$-but rather on the basis of their socioeconomic status, which

rican-free-trade-agreement-nafta (creating the world's largest free trade area that links 450 million people producing $\$ 17$ trillion worth of goods and services).

75. See Immigration and Nationality Act of 1965, 79 Stat. 911 (contributing to Global Mobility Triad process). This Act replaced the former National Origins Formula (which facially discriminated against immigrants on the basis of nationality and, ultimately, race) with the United States' current family/employment-based system. This Act should not be seen as an overt signal from the U.S. government for greater immigration levels; rather, the Act is best seen as part of the 1960's civil rights movement, in that it completely removed the facial consideration of race from U.S. immigration policy.

76. See infra Part III.

77. See generally Bolling v. Sharpe, 347 U.S. 497 (1954) (applying the Equal Protection Clause of the 14th Amendment to race-based discriminations of the federal government).

78. Such a classification might nevertheless survive constitutional scrutiny. See Fiallo v. Bell, 430 U.S. 787 (1977) (finding an illegitimacy classification-which is typically analyzed under intermediate scrutiny-permissible, even if lacking a reasoned explanation from Congress, since it was a classification made in connection with alien admissibility); see also Dunn v. INS, 499 F.2d 856 (9th Cir. 1974) (holding that a Mexican 
happens to peculiarly intermesh, statistically, and as a matter of identity, with race and nationality. ${ }^{79}$ Thus, while the state laws have similar effects, their underlying justifications are also the same once the layers of the "illegalization" arguments are peeled away.

Of course, not every state passed an identical immigration law. But, in general, the mechanisms of the laws are largely similar-with some harsher than others. The goals of state immigration legislation largely overlap as well, though many are more cognizant of economic and political realities that dampen the restrictionist position. In sum, these laws generally seek to reduce the population of "illegal" immigrants within their jurisdictions. The justifications for state restrictionist immigration legislation are largely similar, as outlined in the introduction of this note.

The law most deserving of analysis is Arizona's S.B. 1070, which was the first of these restrictionist immigration laws to be enacted. The law contains the following provisions: ${ }^{80}$

(1) A prohibition on state and local law enforcement agencies against restricting enforcement of federal immigration laws. ${ }^{81}$ Legal residents may sue law enforcement agencies that engage in such activity. 82

(2) A requirement that law enforcement officers "reasonab[ly] attempt" to determine the immigration status of a person in "lawful contact" with a law enforcement officer where "reasonable suspicion" of that person's unlawful presence exists. ${ }^{83}$

(3) Codification of a number of new immigration related crimes, notably failure to carry an alien registration document; 84 hiring or attempting to hire workers on a

citizen was not entitled to discretionary reentry and that statute denying discretionary relief to residents of western hemisphere countries is unconstitutional).

79. See Nicholas P. De Genova, Migrant "Illegality" and Deportability in Everyday Life, 31 ANN. REV. ANTHRO. 419, 433 (2002).

80. The description below outlines the laws as passed. Many provisions have been preliminarily or permanently enjoined by federal courts, as elaborated upon in the "actual effects" discussion below.

81. S.B. 1070, 2d Reg. Sess. § 2(A) (Ariz. 2010) (codified at ARIZ. REV. STAT. ANN. § 11-1051(A) (2012)).

82. Id. $\$ 2(\mathrm{G})$-(I) (codified at ARIZ. REV. STAT. ANN. $\$ 11-1051(\mathrm{G})$-(I) (2012)).

83. Id. $\S 2(\mathrm{~B})$ (codified at ARIZ. REV. STAT. ANN. $\S 11-1051(\mathrm{~A})(2012)$ ).

84. Id. $\S 3$ (A) (codified at ARIZ. REV. STAT. ANN. § 13-1509(A) (2012)). 
street ${ }^{85}$ or entering a vehicle to be hired, 86 if it impedes the normal flow of traffic; for unlawfully present aliens, knowingly applying for or soliciting for work; 87 and recklessly concealing, harboring, or transporting an undocumented alien. ${ }^{88}$

(4) A prohibition on unauthorized ${ }^{89}$ aliens applying for work.

(5) A restriction of all state and local benefits to U.S. citizens and legal permanent residents. ${ }^{90}$

Arizona also passed an immigration law in 2007, which other states have incorporated into their state immigration laws. ${ }^{91}$ The following provisions came as a result of that legislation:

(1) Loss of business licenses for employers of unauthorized aliens; 92 and

(2) A general requirement to use E-Verify ${ }^{93}$ for all employers in the state. ${ }^{94}$

85. Id. § 5(13-2928) (A) (codified at ARIZ. REv. STAT. ANN. § 13-2928(A) (2012)).

86. Id. $\S 5(13-2928)$ (B) (codified at ARIZ. REv. STAT. ANN. § 13-2928(A) (2012)). Interestingly, Sections $5(\mathrm{~A})$ and $5(\mathrm{~B})$ apply to anyone, not just unauthorized aliens.

87. Id. § 5(13-2928) (C) (codified at ARIZ. REv. STAT. ANN. § 13-2928(C) (2012)).

88. Id. § 5(13-2929)(A)(1)-(3) (codified at ARIZ. REV. STAT. ANN. § 13-2929(A)(1)-(3) (2012)).

89. The term "unauthorized alien," as it pertains to SB 1070, means one who is not authorized to work. See id. $\S 5(13-2928)(E)(2)$ (codified at ARIz. REV. STAT. ANN. $\S 13-2928(\mathrm{E})(2)(2012))$. "Unlawful aliens" are unlawfully present in the United States. Certain aliens may be legally present in the United States, but not authorized to work, such as B-Visa tourists or F-2 spouses of foreign students.

90. 2010 Ariz. Sess. Laws 0211, § 1. This separate legislation was House Bill 2162, which amended SB 1070 in certain respects and was passed concurrently with it.

91. Legal Arizona Workers Act of 2007, ARIZ. REV. STAT. ANN. $§ \S 23-211,212.01$, 214(A) (Supp. 2010). These provisions survived a constitutional challenge by the United States Chamber of Commerce. Specifically, the revocation of business licenses for employers of unauthorized aliens, and the general E-Verify requirement were upheld by the Supreme Court. See Chamber of Commerce v. Whiting, 131 S. Ct. 1968 (2011).

92. ARIZ. REV. STAT. ANN. § 23-212.01(F)(1)(c).

93. E-Verify is a service of the United States Department of Homeland Security and Social Security Administration that allows employers to verify the immigration status of their employees. See What is E.Verify?, U.S. CitIzENSHIP \& IMMIGR. SERVICES (Jan. 9, 2013), http://www.uscis.gov/portal/site/uscis/menuitem.eb1d4c2a3e5b9ac89243c6a7543f6d 
Finally, a requirement in S.B. 1070 stipulates that, in implementing the foregoing provisions, no consideration of race, color, or national origin may be used, except as permitted by the Arizona or U.S. Constitutions. ${ }^{95}$

Other independent state provisions of note find themselves largely in Alabama's H.B. 56, the so-called "toughest immigration law in the country." 96 In addition to parallel provisions to those outlined above, this law prohibits the enforcement of many contracts between unlawfully present aliens and other parties; ${ }^{97}$ denies admission to public colleges and universities to unlawfully present aliens; 98 and finally, mandates public schools to determine students' immigration status (lawful or unlawful), to send to the state in a yearly report. ${ }^{99}$ Georgia, ${ }^{100}$ Utah, ${ }^{101}$ and South Carolina ${ }^{102}$ have all enacted provisions similar to Arizona's, but do not include the provisions of the Alabama law.

The theoretical basis for these laws is popularly called "attrition through enforcement," 103 which is touted by restrictionist advocates as a way to stop illegal immigration without the enormous costs of mass forced removal or an unpalatable mass-grant of amnesty. 104 Kris Kobach, ${ }^{105}$ a law professor at the University of Missouri-Kansas City

1a/?vgnextoid=e94888e60a405110VgnVCM1000004718190aRCRD\&vgnextchannel $=e 9488$ 8e60a405110VgnVCM1000004718190aRCRD.

94. ARIZ. REV. STAT. ANN. § 23-214(A).

95. Id. § $13-2929(\mathrm{C})$.

96. Richard Fausset, Alabama Enacts Anti-Ilegal-Immigration Law Described as Nation's Strictest, L.A. TIMES (June 10, 2011) http://articles.latimes.com/2011/jun/10/na tion/la-na-alabama-immigration-20110610.

97. Beason-Hammon Alabama Taxpayer and Citizen Protection Act, 2011 Ala. Laws $535, \S 27$.

98. Id. §8.

99. Id. § 28 .

100. Illegal Immigration Reform and Enforcement Act of 2011, 2011 Ga. Laws 252.

101. Utah Illegal Immigration Enforcement Act, 2011 Utah Laws 021. Utah also passed other laws as part of an immigration package, including some which purport to establish a guest worker program for undocumented workers, and other more immigrant-friendly provisions than other states are employing. See, e.g., Utah Immigration Accountability and Enforcement Amendments, 2011 Utah Laws 018.

102. Act of June 30, 2011, 2011 S.C. Acts 69.

103. S.B. 1070, 2d Reg. Sess. $§ 1$ (Ariz. 2010).

104. See generally Kris W. Kobach, Attrition Through Enforcement: A Rational Approach to Illegal Immigration, 15 TULSA J. COMP. \& INT'L L. 155 (2008) (addressing the false dichotomy that exists within the public debate surrounding immigration).

105. It should be noted that while Mr. Kobach hails from the Republican Party, nativist (and pro-immigration) sentiments do not necessarily split nicely upon party lines. For example, many libertarian or pro-business Republicans favor more open immigration policy. See, e.g., Immigration, THE CATO INST., http://www.cato.org/research/immigration. Conversely, protectionist, pro-union Democrats have historically disfavored open immigration policies-though have more recently come to largely favor more open 
School of Law, and currently Kansas' Secretary of State, has been the most outspoken proponent of such laws, and was instrumental in crafting the state laws outlined above. ${ }^{106}$

Attrition through enforcement intends to make life very difficult for unlawfully present immigrants in these jurisdictions, in some cases even extending punishment to friends and family who consort with those unlawfully present. ${ }^{107}$ It does so through the criminalization of life-sustaining activities-even presence within a state-while simultaneously expanding the permissible role of law enforcement agencies and officers in enforcing federal immigration laws. Certainly, unlike the anti-Chinese laws of the First Era of Globalization, these laws do not seek to ban immigrants on the basis of race; indeed, all of these laws contain explicit provisions barring such a consideration. ${ }^{108}$ Rather, immigrants are excluded on the basis of their "illegality."

Having studied and compared the structure of the laws, it is important to look at the effects-intended and actual —of these laws and compare them to the effects of restrictionist laws from the First Era of Globalization. Quite bluntly, the intended effect of current laws is to reduce the inflows of illegal immigration to states-specifically to "discourage and deter the unlawful entry and presence of aliens and economic activity by persons unlawfully present in the United States."109 Particularly, the aim is to do so through Mr. Kobach's "attrition through enforcement" regime. ${ }^{110}$

In reality, many parts of the laws have not had much chance to take effect, as federal judges have blocked many of the provisions. ${ }^{111}$ The provisions of Arizona's law that have taken effect are (1) the E-Verify requirement and suspension of business licenses, ${ }^{112}(2)$ the requirement of law enforcement agencies to not restrict enforcement of federal immigration laws, (3) the prohibition of public benefits, and (4) the

immigration policies. See Joseph T. Hapak, Book Review, 8 J. AM. ETHNIC HIST. 124 (1988) (reviewing GWENDOLYN MINK, OLD LABOR AND NEW IMMIGRANTS IN AMERICAN POLITICAL DEVELOPMENT: UNION, PARTY, AND STATE, 1875-1920 (1986)).

106. See Julia Preston, Lawyer Leads an Immigration Fight, N.Y. TIMES (July 20, 2009), http://www.nytimes.com/2009/07/21/us/21lawyer.html.

107. See Beason-Hammon Alabama Taxpayer and Citizen Protection Act, 2011 Ala. Laws 535, $\$ 13$ (criminalizing any attempt to "conceal, habor, or shield from detection ... encourage or induce ... to come in or reside in [Alabama] ... or transport [any alien with knowledge or reckless disregard of their unlawful presence]").

108. See, e.g., ARIZ. REV. STAT. ANN. § 13-2929(C) (2010).

109. S.B. 1070, 2d Reg. Sess. $\$ 1$ (Ariz. 2010).

110. See id. ("[T]he intent of [SB 1070] is to make attrition through enforcement the public policy of all state and local government agencies in Arizona.").

111. See supra note 15 and infra note 114.

112. The Supreme Court recently approved of these provisions. Chamber of Commerce v. Whiting, 131 S. Ct. 1968, 1986-87 (2011). 
requirement that law enforcement officers make a "reasonable attempt" to determine a person's immigration status upon a lawful contact with reasonable suspicion of unlawful status. The provisions of Alabama's law that have been upheld notably include (a) the requirement to ascertain immigration status during a lawful stop by a law enforcement officer, ${ }^{113}$ and (b) the requirement of proof of lawful presence to conduct business with Alabama governments. ${ }^{114}$

In addition to the legal effect of these laws, the laws' perceived effects-and the perception of immigrant hostility in general-have caused real consequences among immigrant populations. The Alabama law, in particular, has led to a flight of legal and "illegal" immigrants from the state. ${ }^{115}$ Arizona's law has had similar effects, though much of the immigrant flight from the state can be attributed to the impact of the recession mixing with the effect of perceived persecution from the legislation. ${ }^{116}$ Thus, the restrictionist advocates have at least partially achieved their goals, even without full implementation of the laws. ${ }^{117}$

113. In contrast to the Arizona litigation, where an analogous provision did remain preliminarily enjoined. United States v. Arizona, 641 F.3d 339, 353-54 (9th Cir. 2011), aff'd in part, rev'd in part, remanded $132 \mathrm{~S}$. Ct. 2492 (2012). However, the U.S. Supreme Court later removed the injunction as to that provision, holding it is not preempted by federal law. Arizona v. United States, 132 S. Ct. at 2508.

114. See United States v. Alabama, 691 F.3d 1269, 1282-83, 1285-98 (11th Cir. 2012) (striking down provisions (1) requiring aliens to carry registration documents, (2) criminalizing knowing application, solicitation, or performance of work by an unauthorized alien, (3) criminalizing transporting, harboring, and inducement of aliens, (4) prohibiting state tax deductions for unlawful alien employees, (5) providing a cause of action for U.S. citizens not hired by an employer who instead hires an unlawful alien, and (6) prohibiting courts from enforcing any contracts entered in to, in part, by an unlawful alien); Hispanic Int. Coal. of Alabama v. Alabama, 691 F.3d 1236 (11th Cir. 2012) (striking down the citizenship verification requirement for students as violating the Equal Protection Clause).

115. Rawls, supra note 42 .

116. Illegal Immigrants Leaving Arizona Over New Law, CBS News (Apr. 29, 2010, 10:14 AM), http://www.cbsnews.com/stories/2010/04/29/national/main6442729.shtml.

117. Of course, there are numerous unintended effects of the laws as well, including remaining immigrants keeping a "low-profile," non-cooperation with law enforcement officers in the reporting of criminal activity, and failure to seek medical attention, all due to fear of apprehension. See, e.g., Daniel González, Senate Bill 1070: One Year Later, ARIz. REPUBLIC (Apr. 23, 2011, 12:00 AM), http://www.azcentral.com/12news/news/articles/2011/ 04/23/20110423arizona-immigration-law-impact-year-later.html. Further, if flight of immigrants was, as stated, merely a means to economic advancement of the targeted jurisdictions, early empirical data indicates that these laws generally failed. Professor Huyen Pham undertook an extensive empirical study of restrictionist laws enacted between 2005 and 2007. See Huyen Pham \& Pham Hoang Van, The Economic Impact of Local Immigration Regulation: An Empirical Analysis, 32 CARDOZO L. REV. 485 (2010). The study shows that, contrary to the economic arguments offered against "illegal" immigration, restrictionist laws led to a small decrease in employment rates. $I d$. at 488 . 
Compared to the laws in the First Era of Globalization, current laws' intended and actual effects largely mirror each other, though current state legislators, not daring to legislate on the basis of race, do not implicate the constitutional concerns which arose in challenges to anti-Chinese laws.

\section{JUSTIFYING PARADIGMS}

Finally, we must examine what lies behind these laws; how their proponents justify the end result of a reduction in illegal (and overall) migration to their jurisdictions. Further, to understand how globalization plays into these justifications, we will compare them to justifications given for anti-Chinese immigration laws. Four principal arguments were identified above: (1) The Fiscal Argument, (2) The Economic Argument, (3) The Security Argument, and (4) The Rule of Law or "Illegality" Argument.118 These arguments are best divided into (a) Economic Arguments (Economic and Fiscal) and (b) "Illegality" Arguments (Security and Rule of Law).

\section{A. Economic Arguments Against Global Labor Migration}

The restrictionist lobby often highlights the fiscal cost of immigration, as evidenced by the entitlements that immigrants and their families allegedly "take."119 Yet, nonimmigrants, lawful immigrants, and "illegal" immigrants alike are all barred by federal law from receiving any means-tested benefit directly. ${ }^{120}$ They may, however, claim entitlements on behalf of their U.S. citizen children, since those children are not otherwise barred. This argument, while implicating critical notions of national belonging, which globalization impacts, is focused on nationality laws, and not immigration laws. Thus, a lengthy discussion is beyond the scope of this piece. Suffice to say that these arguments would be better focused on either the merits of entitlement laws themselves or the merits of the nationality laws, rather than casting blame solely on those who choose to immigrate legally or "illegally."

118. See supra Part I.

119. MARTIN \& RUARK, supra note 29.

120. See Personal Responsibility and Work Opportunity Reconciliation Act of 1996, Pub. L. 104-193, 110 Stat. 2105, $\S$ 400-51 (1996). Those without lawful immigration status are further barred from various benefits by federal, state, and local regulations. See generally Huyen Pham, When Immigration Borders Move, 61 FLA. L. REv. 1115 (2009) (outlining and critiquing such regulations). 
Additionally, the restrictionist immigration lobby consistently claims that increased levels of immigration-regardless of its illegality-has a negative economic effect on natives in the United States. 121 The argument goes that immigrants come to the receiving country, and "take" American jobs with vastly higher wage levels.122 Thus, the native no longer has the opportunity to fill that position, since the immigrant is often willing to work for less than the native; as from the immigrant's perspective, the wage level is a vast improvement over that prevailing in the sending country. ${ }^{123} \mathrm{Here}$, we see the negative native reaction to Ricardo's theory of comparative advantage as applied to global labor migration. ${ }^{124}$ If true, this should show a negative impact on native employment and wage rates.

This argument has three fundamental flaws. Natives are not necessarily concerned about labor-market competition within their own labor market, ${ }^{125}$ despite the anti-immigrant lobby's claims. Secondly, the basic notion of an "American" job is specious; the definition is vague and ultimately circular. If an "American" job is one that belongs to those legally authorized to work in the United States (as the arguments against illegal immigration must presuppose), then the definition becomes a self-fulfilling prophecy: American jobs belong only to those the government deems expedient, which as explained below, currently does not include poor, unskilled, non-native laborers. ${ }^{126}$ If, on the other

121. RUARK \& GRAHAM, supra note 47.

122. There is clear empirical support for the proposition that international labor migration flows are highly responsive to the per capita income rate in the receiving country. See Francesc Ortega \& Giovanni Peri, The Effect of Income and Immigration Policies on International Migration 3 (Nat'l Bureau of Econ. Research, Working Paper No. 18322, 2012).

123. This argument has typically been seen as a factor influencing anti-immigrant attitudes based on labor market competition fears. But see Jens Hainmueller \& Michael J. Hiscox, Educated Preferences: Explaining Attitudes Toward Immigration in Europe, 61 INT'L ORG. 399, 413-38 (2007). The authors conclude that the 2003 European Social Survey indicates that labor-market competition fears alone do not correlate with support for restrictionist immigration policies. Instead, they argue that higher native education levels correspond with an increased likelihood to support pro-immigration policies. This is a plausible explanation, yet it presumes perfect information flows to the survey's respondents. Namely, the respondent must understand their own labor market position relative to the immigrant's, and further presumes that identifying the immigrant only as "from [sending country]" will sufficiently identify that immigrant. Additionally, respondents may not necessarily be opposed to labor market competition within their own labor market, but the national labor market in general (i.e., the notion of "American" jobs).

124. See supra note 22 and accompanying text.

125. See Hainmueller \& Hiscox, supra note 123.

126. Some scholars, notably Joseph Carens, argue that it is morally indefensible for countries to refuse the admission and employment of law-abiding immigrants, no matter 
hand, an "American" job belongs only to U.S. citizens, that definition is underinclusive, as many immigrants are lawfully authorized to work in the United States.

Most importantly, theory and experience have shown that greater immigration levels do not cause higher unemployment or wage levels in the receiving country. Many scholars who study the economics of global labor migration have applied various models of labor market analysis to study the impact of hypothetical increases or reductions in global immigration levels. ${ }^{127}$ To exemplify the theoretical aspects of this rebuttal with a more accessible model, imagine the world existed of two countries, Argonia and Nibenay. Argonia is a well-developed nation, with high wage levels and a high standard of living. Nibenay is still developing, with fast rates of growth, but overall much lower wage levels than those found in Argonia. According to labor economists, loosening immigration restrictions for low-skilled Nibenayen laborers does indeed produce a vast comparative gain in overall wage levels to these immigrants. ${ }^{128}$ However, the model also suggests, among workers similarly situated, (1) a relatively small decline in Argonia's wage levels, and (2) a relatively small increase in Nibenay's wage levels, due to decreased labor supply. ${ }^{129}$ Overall, global welfare rises to varying degrees depending on the elasticity of the Argonian and Nibenayen labor demand curves, various externalities caused by the influx of migrant labor, productivity differences, and diminishing returns of labor migration. ${ }^{130}$ At the end of the day, the economic models suggest that through open immigration policies, gross world product increases, and that although receiving-country wage rates decrease, they do not decrease drastically.

In addition to theoretical models, the real world has data to test this economic theory. Each successive EU enlargement constitutes the most recent phenomenon where barriers to labor migration have come down. David G. Blanchflower and Chad Shadforth authored an impressive study on the effect of labor migration from the A8 and A10 countries ${ }^{131}$

their background. See generally Joseph H. Carens, Aliens and Citizens: The Case for Open Borders, 49 REV. POL. 251 (1987).

127. See Michael A. Clemens, Economics and Emigration: Trillion-Dollar Bills on the Sidewalk?, J. ECON. PERSPS., Summer 2011, at 83, 85 (assembling a list of various models and their results on the global economy).

128. Id. at 89 .

129. Id.

130. That is, at some point, the rate of migration will cease depending on the number of available migrants left, and the conditions in the sending country.

131. A8 refers to the Czech Republic, Estonia, Hungary, Latvia, Lithuania, Poland, Slovakia, and Slovenia. A10 means these countries, plus Bulgaria and Romania. David G. Blanchflower \& Chad Shadforth, Fear, Unemployment and Migration, 119 ECON. J. F136, 
on the United Kingdom. ${ }^{132}$ The study found that nominal wage levels, among natives in occupations most likely to be taken by immigrants, increased in the time period studied, but the influx of migration caused their real wages to decrease. ${ }^{133}$ However, the data also suggests that inflationary pressures and the natural unemployment rate decreased, due to the excess of new labor supply over new labor demand. ${ }^{134}$ In essence, wages did not keep up with inflation, but natives-generally speaking-did not lose their place in the labor market due to an influx of labor migrants. Thus, from both a theoretical and real-world analysis, the economic arguments-while still retaining some validity-are weakened substantially. Further, from a globalized viewpoint, open migration policies are a net world good.

\section{B. The Rule of Law Arguments Against Global Labor Migration: The "Illegalization" of Poverty in the Current Era of Globalization}

Even if increased labor migration is proven to be beneficial, additional barriers to migration exist. As Jennifer Gordon astutely puts it, "people are not bananas"; that is, easing barriers to the flow of people has profound societal and cultural effects, as compared with easing barriers to goods and capital. ${ }^{135}$ In short, if a given migratory group enters a receiving country with natives who are wholly dissimilar in cultural and societal aspects, some friction and resistance will inevitably result.

During the First Era of Globalization, this phenomenon was all too apparent. As discussed above, the influx of a racially, culturally, and societally dissimilar group sought by the receiving country's vast labor demand prompted reactionary and racially discriminatory immigration laws, which eventually barred the Chinese from immigration on the basis of their race and nationality.

Today, immigration laws can be equally harsh, but cannot be justified on similar bases. Thus, we see none of the justifications-even from the most restrictionist lobbies-containing assertions of racial or cultural superiority, though they do include notions of societal

F136 (2009), available at http://www.dartmouth.edu/ blnchflr/papers/fear\%20unemploym ent\%20fulltext.pdf.

132. Id. at F137.

133. Id. at F179.

134. Id. at F179-80

135. Jennifer Gordon, People are Not Bananas: How Immigration Differs from Trade, 104 NW. U. L. REv. 1109, 1110-11 (2010). 
superiority and tout the benefits of homogeneity. ${ }^{136}$ Certainly, any official justification of these laws focuses on the "illegality" of its targets, and dares not touch on race or culture. ${ }^{137}$ Thus, restrictionist policies are justified in terms of perceived economic harms and the pervasive "illegality" with which many immigrants are ascribed-regardless of how they came to the United States. This "illegality" is seen as harm-in and of itself-to the rule of law, and also carries various national security concerns with it. 138

But how does admonishing "illegal" immigration tie into racial or cultural animus? After all, when hundreds of thousands of people per year break a country's civil and criminal immigration laws, those immigrants are indeed violating the rule of law, which in turn cheapens such laws, and leads to more individuals being less likely to follow these laws. ${ }^{139}$ This is the Rule of Law Argument, and here, restrictionists can identify a valid harm.

Restrictionists also have a further valid concern in the Security Argument. This argument asserts that since aliens who enter the United States without inspection evade detection and inspection by immigration authorities, these "illegal" immigrants pose a security and health risk to the nation. ${ }^{140}$ This is another plausible concern; without some form of inspection examining an immigrant's health, security risks, or criminal history (which most, if not all, U.S. citizens must at some point face), the national security of the United States is indeed put at risk.

Yet, the way a certain segment of immigrants has been "illegalized" obscures two separate classes of "illegal" immigrants in this category: (1) those inadmissible on the basis of criminal, security, and health concerns, and (2) those inadmissible because they have no other path of legal immigration available to them. The former is certainly a valid concern, and most scholars, lobbies, and policymakers would agree to keep such laws barring them from admission.

\footnotetext{
136. See, e.g., Assimilation (2002), FED'N AM. IMMIGR. REFORM, http://www.fairus.org/issue/Assimilation (last visited Mar. 2, 2013).

137. See, e.g., S.B. 1070, 2d Reg. Sess. $\S 1$ (Ariz. 2010). Note, however, the recent revelations about the bill sponsor's likely motivations. See Alia Beard-Rau, ACLU: Pearce E-Mails Prove SB 1070 Was Racially Motivated, ArIz. RePUBLIC (Jul. 19, 2012, 5:56 PM), http://www.azcentral.com/arizonarepublic/news/articles/2012/07/19/20120719sb-1070. pearce-aclu-emails.html.

138. See, e.g., What's Wrong With Illegal Immigration? (2005), FED'N AM. IMMIGR. REFORM, http://www.fairus.org/issue/whats-wrong-with-illegal-immigration (last visited Mar. 2, 2013).
}

139. See id.

140. See Scarborough, supra note 45 . 
However, for the latter group, there is no "line" in which the immigrant can queue; thus, they enter illegally. The would-be migrant to the United States often has no other recourse than to break such laws after completing a utility calculus for their current employment prospects versus their employment and wage prospects in the United States-even factoring in the negative consequences of breaking immigration laws and the dangers inherent in traversing a sparse and treacherous border.

The incentive of the would-be migrant worker to disregard United States immigration law exists because there is absolutely no efficient, legal process for low-skill migrants to immigrate to the United States. Processes exist for highly-skilled workers, ${ }^{141}$ those with pre-existing family ties to U.S. citizens or legal permanent residents, ${ }^{142}$ and those lucky enough to be chosen in the Diversity Visa (DV) program. ${ }^{143}$ Processes also exist for temporary work in the United States, such as $\mathrm{H}-2 \mathrm{~A}$ and $\mathrm{H}-2 \mathrm{~B}$ visas. ${ }^{144}$ However, these visas do not provide a pathway to lawful permanent residency and cannot provide a pathway to citizenship. ${ }^{145}$ Thus, those excluded from lawful immigration are invariably unskilled and poor.

Additionally, other factors tend to make "illegal" immigrants come from a dissimilar race, culture, and society. The immigrants with the most to gain come from developing countries, ${ }^{146}$ which thanks to colonialism and-some argue- to today's globalization, ${ }^{147}$ constitute the racially, culturally, and socially dissimilar regions of the developing world. Of course, in the case of the United States, Mexico's geographical proximity plays a critical role as well. Thus, "illegal" immigrants invariably constitute low-income, low-skilled workers from a dissimilar

141. See 8 U.S.C. $\& 1153$ (b) (2006). This provision does allow for unskilled labor migration; however, a petition for immigration must be accompanied by a labor certification, stating that no American workers are available to take the job. Id. Employers are often unwilling to complete this time-consuming and bureaucratic procedure. At any rate, there is currently a delay of approximately six years for issuance of visas. See BUREAU OF CONSULAR AFF., Immigrant Numbers for August 2013, IX VISA BuLL. No. 59 (2013), available at http://travel.state.gov/pdf/visabulletin/visabulletin_augu st2013.pdf.

142. See 8 U.S.C. $\S \S 1151(\mathrm{~b})(2)(\mathrm{A})(\mathrm{i}), 1153(\mathrm{a})$.

143. See 8 U.S.C. $\$ 1153(\mathrm{c})$. Of course, residents of North or Central America need not apply; the DV is available only to natives of countries with relatively low immigration rates to the United States. See BUREAU OF CONSULAR AFF., supra note 141.

144. See 8 U.S.C. $§ 1011(\mathrm{a})(15)(\mathrm{H})$.

145. See 8 U.S.C. $\$ 1427$ (a) (requiring five years of lawful permanent resident (i.e., green card) status as a prerequisite for U.S. naturalization).

146. See generally Ortega \& Peri, supra note 122, at 3.

147. See, e.g., Arie M. Kacowicz, Globalization, Poverty, and the North-South Divide, 9 INT'L STUD. REV. 565, 568 (2007). 
race, culture, and society. They are illegal mainly because of factors beyond their control, especially when they come, as they often do, from countries with inadequate educational and employment opportunities.

In sum, the foregoing reveals a few elements of the "illegality" and Rule of Law Argument that are specious. Rhetoric that tells an intending immigrant to "get in line!" has no real target or effect; undoubtedly, many immigrants would "get in line" if a line existed. Further, if the laws were changed to allow for unchecked low-skill immigration from dissimilar cultures-thereby removing an immigrant's "illegality"-restrictionist lobbies would not be placated, because of their opposition to immigration as a whole.148 Their arguments for immigration restrictions based on either Rule of Law or Security concerns would fall apart, assuming an efficient, affordable, and widely available system of immigration for these low-skill, low-income laborers, which would scrutinize immigrants for criminal or security issues.

Thus, we are not really dealing with opposition to "illegal" immigration as justifying these new state immigration laws; it is opposition to low-skilled immigration from dissimilar cultures. Such legislation arises mainly because of fear of unwanted labor competition, ${ }^{149}$ which, as shown above, is not a valid concern.

It is here we see a striking parallel to the justifications underlying the laws of the First Era of Globalization. As previously discussed, anti-Chinese laws of that time were justified openly on the basis of unwanted labor competition and fears of racial and cultural heterogeneity. Today, we cannot justify what are, in effect, discriminatory laws on the basis of race or cultural differences without being kicked out of the public square. Thus, we have "illegalized," wittingly or not, the presence of the vast majority of racially and culturally dissimilar immigrants. This race-neutral term serves to reach the ends of racial and cultural discrimination, even if laws based on this concept are not justified squarely on such a basis.

"Illegalization" serves racially and culturally discriminatory ends by inculcating natives with a predisposition against "illegal" immigrants, using the Rule of Law and Security arguments to obscure the difference between criminal and security-based "illegal" immigrants and those for

148. See FED'N AM. IMMIGR. REFORM, supra note 50.

149. Either unwanted as to one's own labor market, or, as implied by Hainmueller and Hiscox, opposition to competition in the national labor market, irrespective of direct competition from immigrants in a native's labor market. See Hainmueller \& Hiscox, supra note 123. 
whom no path of immigration exists. ${ }^{150}$ "Illegal" immigrants are normatively seen as bad.

Then, since the conception of "illegal" immigrants happens to apply to racially, culturally, and societally dissimilar immigrants, due to the factors identified above, laws against illegal immigration cannot escape the racist castigations that immigration proponents levy against restrictionist laws, lobbies, and legislators. In the minds of many, including the media and immigrants themselves, ${ }^{151}$ these are race-based immigration laws. It also seems that in the minds of some prominent legislators, racism motivated their promotion of this legislation. ${ }^{152}$ Indeed, Critical Race Theory scholars suggest that such laws are often passed because of underlying racial sentiments; some would argue that the entirety of the immigration regime in the United States exists to codify a racially disparate "other" as "alien," thereby legitimizing disparate, harmful, and at times "inhumane" treatment of that "other." 153 At the end of the day, we are left with laws that enforce an effectively racially based exclusionary policy, couched in the politically palatable language of "illegalized" immigration, that have the very same effect as the anti-Chinese laws of the First Era of Globalization.

\section{CONCLUSION: RETHINKING IMMIGRATION POLICIES IN A GLOBAL WORLD}

Given that these restrictionist arguments have been disarmed, what stands in the way of a completely open migration policy? Again, quite an

150. Entirely left out of the "illegal" immigrant concept are violators of immigration laws with violations not related to entry. Examples of this could include the German student who overstayed her F-1 Visa, or her husband on an F-2 status who worked in a restaurant without authorization. See 8 U.S.C. $\S 1101(\mathrm{a})(15)(\mathrm{F})(\mathrm{i})$, (ii) (authorizing nonimmigrant status for aliens attending university in the United States); $1227(\mathrm{a})(1)(\mathrm{C})(\mathrm{i})$ (authorizing removal of aliens who fail to comply with the conditions of their nonimmigrant status); 8 C.F.R. $\$ 214.2$ (f)(5)(i), (iv) (establishing various time limits for F-1 status holders); (f)(15)(i) (establishing acceptance of employment as a violation of F-2 status). Though these are "illegal" immigrants insofar as they have violated federal immigration law-and are thus the subjects of federal and state laws on the topic-they are not included in the common conception of "illegal" immigrants.

151. See, e.g., Massimo Calabresi, Is Racism Fueling the Immigration Debate?, TIME (May 17, 2006), http://www.time.com/time/nation/article/0,8599,1195250,00.html.

152. See, e.g., Beard-Rau, supra note 137.

153. See Mary Romero, Crossing the Immigration and Race Border: A Critical Race Theory Approach to Immigration Studies, 11 CONTEMP. JUST. REV. 23, 28 (2008) (cataloging scholarly work on race-and-immigration issues, including Kevin R. Johnson, "Aliens" and the U.S. Immigration Laws: The Social and Legal Construction of Nonpersons, 28 U. MIAMI INTER-AM. L. REV. 263 (1996)). 
important point: "people are not bananas." 154 Whether racial, cultural, and social integration is a good thing is a wholly separate question from how these issues are avoided ${ }^{155}$ by modern restrictionist advocates.

What this note has attempted to bring out of the literature, law, and policy discussions, through a comparison with the laws in the First Era of Globalization, is the legislature's effective obscuring of this type of discussion. The blatantly racist and discriminatory laws against Chinese immigrants were eventually repealed. Repeal was accomplished on the basis of a (mostly) national consensus against racial discrimination. ${ }^{156}$ Now that our laws cannot draw such discriminatory lines or be justified on such bases, the question is twofold: (1) can the American public recognize that these laws subtly discriminate along racial lines, and (2) are they willing to have the discussion on whether racially, culturally, and socially dissimilar individuals ought to be allowed to migrate to the United States? This note argues that the public must recognize the subtleties of U.S. immigration laws-as this piece has demonstrated-and they must be willing to have a discussion of the latter. Otherwise, the public does not really know what effect its laws are having, and laws made in the mold of "illegality"-like those in Arizona, Alabama, and elsewhere-will continue to pop up with highly damaging effects to immigrants, natives, and a unified national immigration policy.

One final point on globalization's role: the incentives of globalization are not going away. With the current level of technology and deep integration of the world economy, immigration laws that seek to keep the "other" out serve only to run against the grain of an inevitable economic, social, political, and cultural integration process. Laws such as those in Alabama and Arizona-even if they succeeded in reversing globalization's integrating effects-will only be a temporary reprieve against the forces of globalization, or else serve to isolate a nation or state from what will continue to be a dominating force. Given that free immigration increases gross world product, ${ }^{157}$ and is itself the final expression of a globalized world, restrictionist advocates are hurting businesses, immigrants, natives, and nations alike, and are engaging in a fruitless effort against a relentless process.

154. See Gordon, supra note 135.

155. Mostly. See Beard-Rau, supra note 137.

156. Though the Magnuson Act repealed the Chinese Exclusion Act in 1943, ethnic Chinese could not own property in many states until 1965-after the passage of the Civil Rights Act and the current Immigration and Nationality Act of 1965. See JAPANESE AM. Citizens League, An Unnoticed Struggle: A Concise History of Asian AMERICAN CIVIL RIGHTS ISSUES 10 (2008), available at http://www.jacl.org/public_policy/documents/ An\%20Unnoticed\%20Struggle.pdf.

157. See Clemens, supra note 127 , at 89 . 
